\title{
Retrospective analysis of risk factors for development of biliary fistula after liver cyst hydatid surgery
}

\section{Karaciğer hidatik kist cerrahisi sonrası oluşan safra fistülünün gelişimindeki risk faktörlerinin retrospektif analizi}

\author{
Emin Köse ${ }^{1}$, Nilay Tuğba Baz ${ }^{1}$, Deniz Tazeoğlu ${ }^{1}$, Mehmet Emin Gürbüz ${ }^{1}$, Hasan Tok ${ }^{1}$, Ayhan Özsoy ${ }^{1}$, Servet \\ Rüştü Karahan ${ }^{1}$
}

\begin{abstract}
Aim: Hepatic hydatidosis is common parasitosis in Turkey and caused by Echinococcus granulosus. Biliary fistula is the most common complication after liver hydatid cyst surgery. The aim of this study was to investigate an appropriate treatment strategy for patients whose biliary fistula might develop, by revealing variables that affect biliary fistula.

Methods: A total of 118 patients who underwent liver hydatid cyst surgery were included in this study. The following variables were analyzed between patients with biliary fistula (group 2) and without fistula (group 1): Age, gender, hematologic and liver function tests, and features of the cysts (type, cyst size, number, and localization).

Results: Cystobiliary fistula was detected in 19 (16\%) of 118 patients. In-group 2, cyst size, white blood cell, alkaline phosphatase and g-Glutamyl transpeptidase levels were higher than group 1 on univariate analysis ( $\mathrm{p}=0.03, \mathrm{p}=0.008, \mathrm{p}=0.04$ and $\mathrm{p}=0.001$, respectively). In the multivariate model, only cyst diameter remained as an independent predictor (odds ratio $0.03,95 \%$ confidence interval 0.002 to $0.06 ; \mathrm{p}=0.03$ ) On the receiver operating characteristic curve, the $100 \%$ sensitive, $100 \%$ specific, and optimal cutoffs of the cyst diameter were $7.5 \mathrm{~cm}, 4.0 \mathrm{~cm}$ and $14.6 \mathrm{~cm}$, respectively (The area under the receiver operator characteristic curve was 0.67 ). Conclusion: Preoperative cyst size is a valuable parameter for predicting biliary fistula. Our study suggests that cyst size greater than $7.5 \mathrm{~cm}$ is a risk factor for biliary fistula.
\end{abstract}

Key words: Hydatid liver disease, cystobiliary fistula, Echinococcus granulosus

Öz

Amaç: Karaciğer hidatik kist hastalığı Echinococcus granulosus'un neden olduğu, Türkiye'de yaygın görülen bir parazitozdur. Karaciğer kist hidatik cerrahisi sonrası en sık gelişen komplikasyon safra fistülüdür. $\mathrm{Bu}$ çalışmadaki amacımız safra fistülü gelişimini etkileyen değişkenleri ortaya koymak ve uygun tedavi seçeneklerini incelemektir.

Yöntemler: Bu çalışmaya karaciğer kist hidatik cerrahisi uygulanmış olan 118 hasta dahil edildi. Hastalar safra fistülü gelişen (grup2) ve gelişmeyen (grup1) olarak iki gruba ayrıldı ve değişkenler analiz edildi: yaş, hematolojik ve karaciğer fonksiyon testleri ve kistin özellikleri (tip, kist boyutu, sayısı ve yerleşim yeri).

Bulgular: 118 hastanın 19 (\%16)'unda safra fistülü saptandı. Grup 2'de kist boyutu, lökosit, alkalin fosfataz ve g-Glutamin transpeptidaz değerleri tek değişkenli analiz sonucuna göre grup 1'den daha yüksekti $(\mathrm{p}=0,03$, $\mathrm{p}=0,008, \mathrm{p}=0,04, \mathrm{p}=0,001)$. Çok değişkenli analiz sonucuna göre; safra fistülü gelişimine etki eden tek bağımsız değişken yalnızca kist boyutu olarak saptandı (olasılık oranı $0.03,95 \%$ güven aralığı $0,002-0,06 ; p=0,03$ ). Işlem karakteristik eğrisine göre, kist boyutlarının $100 \%$ duyarlılık, $100 \%$ özgüllük ve eşik değeri, sırasıyla $7,5 \mathrm{~cm}, 4,0$ $\mathrm{cm}$ ve 14,6 cm olarak bulundu. (Eğrinin altındaki alan 0,67).

Sonuç: Safra fistülünün tahmininde preoperatif kist boyutu önemli bir parametredir. Bizim çalışmamıza göre; kist boyutunun $7,5 \mathrm{~cm}$ 'den büyük olması safra fistülü gelişimi için bir risk faktörüdür.

Anahtar Kelimeler: Karaciğer kist hidatik hastalığı, safra fistülü, Echinococcus granulosus
Health Sciences University, Okmeydani Education and Research Hospital, Department of General Surgery, Istanbul, Turkey.

Ethics Committee Approval: The study wass approved by the local ethical authority. Etik Kurul Onayı: Çalışma lokal etik komite tarafindan onaylanmıştır.

Conflict of Interest: No conflict of interest was declared by the authors.

Çıkar Çatışması: Yazarlar çıkar çatışması bildirmemişlerdir.

Financial Disclosure: The authors declared that this study has received no financial support. Finansal Destek: Yazarlar bu çalışma için finansal destek almadıklarını beyan etmişlerdir.

Geliş Tarihi / Received: 23.02.2019

Kabul Tarihi / Accepted: 27.02.2019

Yayın Tarihi / Published: 15.03.2019

Sorumlu yazar / Corresponding author: Emin Kose

Adres/Address: Kaptan Paşa Mahallesi, Darülaceze Cad. No:25, 34384 Şişli, İstanbul, Turkey e-posta: dreminkose@yahoo.com Tel/Phone: (+90) 02123145555

Copyright $($ ACEM 


\section{Introduction}

Hepatic hydatidosis is an endemic disease in South America, Middle East, East Mediterranean, African countries and Turkey. Liver hydatid cyst (LHC) is most common caused by Echinococcus granulosa. LHC can be symptomatic due to its size, location, and involvement of the biliary tree and infectious $[1,2]$.

Previous studies have reported that $5-25 \%$ of cases with LHC are associated with biliary tracts and can be complicated by 40-60\% [3]. LHC can cause cystobiliary fistula (CBF) in 1-17\% of patients with cyst-biliary communication after surgery or minimally invasive treatments $[4,5]$. The treatment strategy varies depending on time of the realizing cyst-biliary communication, however the gold standard method is not determined for diagnosis of cyst-biliary communication [6]. There are some studies on scoring systems that are about CBF after hydatid cyst surgery; but still couldn't determine a standard approach for clinical practice [7].

Previous studies have shown that the cyst size, cyst location, and the compression on biliary tract may cause CBF [8, 9]. Even though there are many studies about evaluating cystbiliary communication with preoperative imaging techniques, there are so less studies on relation between preoperative biochemical tests and biliary fistula $[10,11]$

The aim of this study was to investigate appropriate treatment strategy for patients whose biliary fistula might develop, by revealing variables that affect biliary fistula.

\section{Material and methods}

The records of all patients who underwent surgery for LHC at Okmeydani Research and Educational Hospital during the period from April 2014 to May 2017 were retrospectively analyzed. This was a retrospective analysis of prospectively collected data and approved by the local ethical committee at Okmeydani Research and Educational Hospital (date: May $9^{\text {th }}$, 2017; decision no: 653). All of the procedures were in accordance with the World Medical Association Helsinki Declaration of 1964 and later versions. Written consent could not be obtained from all participants for being included in this retrospective study.

A total of 132 patients were included in the study considering these inclusion criteria (1) Patients underwent open or laparoscopic liver surgery for LHC from April 2014 to May 2017 (2) Patient has a preoperative computerized tomography in a month.

Exclusion criteria were as follows: (1) Liver diseases such as benign and malignant liver tumors, and hepatic abscess in addition to LHC; (2) Radical liver surgery such as hepatectomy for LHC (3) Biliary diseases such as bile duct stones and structure in addition to LHC.

In addition, because of high preoperative serum bilirubin and liver function test levels, ten patients who were performed preoperative ERCP and four patients with lack of data were also excluded from the study. At the end, a total of 118 patients were included in this study (Figure 1).

The data of the remaining 118 patients, including age, sex, laboratory data (alanine transaminase (ALT) (U/l), aspartate transaminase (AST) (U/l), alkaline phosphatase (ALP) (U/L), gGlutamyl transpeptidase (GGT) (U/L), total and direct bilirubin (mg/dl) and hematologic tests), cyst type, cyst size and location, presence of intraoperative bile leakage and type of the procedure if bile leakage was present, type of surgery, presence of a postoperative biliary fistula, and length of hospital stay were recorded. The stage of each cyst was determined according to Gharbi classification [12]. All patients have pre-operative and post-operative laboratory tests and preoperative CT scan in a month.

\section{Surgical Technique}

As a surgical technique, in addition to partial cystectomy; unroofing, omentoplasty and drainage were done by surgeon decision and cyst properties. Hypertonic saline was used as the scolicidal agent. After cyst was aspirated, hypertonic saline was injected into the cyst cavity and 10 minutes later the cyst cavity was opened. After evacuating the cystic membranes and vesicles, the cyst cavity was explored for biliary leakage, and these patients were recorded. Based on the individual surgeon' decision and location of the cyst (near the gall bladder), cholecystectomy was performed on the patients that had biliary leakage in the cyst cavity and tried to find the communication with biliary tree by injected serum saline or methylene blue through the cystic duct. The localizations of the biliary leakage were then sutured. T-tube drainage was performed in patients whom location of biliary leakage was not detected. The drain was inserted into the cyst cavity in all patients. Postoperatively, if bile leakage was detected in drains, defined as Group1 and if not detected, defined as Group 2, postoperatively.

All patients were treated with albendazole $10 \mathrm{mg} / \mathrm{kg}$ after surgery. The patients with T-tube drainage were performed cholangiography at the first week. T-tube was clamped and removed after 4 weeks when there was no leakage on the first week' cholangiography.

\section{Statistical Analysis}

Data analyses were performed using JMP version 13.1 (SAS, Cary, NC). Quantitative values were represented as mean \pm standard deviation, while independent categories were represented as number $(\%)$. In-group comparisons, the Student $t$ test was used to evaluate the differences between continuous variables and the chi-square test was used for categorical variables. Parameters with a $\mathrm{P}$ value of less than or equal to 0.05 on univariate analysis were included in the Cox Proportional Hazards Model to identify independent predictors of bile leakage. A P value of less than 0.05 was considered significant. Receiver operating characteristic (ROC) curves was used to evaluate optimal cut-off values of cyst diameter in relation to bile leakage.

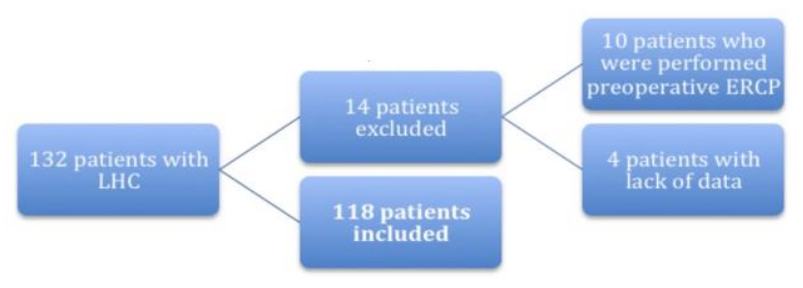

Figure 1. Flow chart for included patients in this study

\section{Results}

There were 118 patients, $74(63 \%)$ female and $44(37 \%)$ male patients with a mean age of $42 \pm 16.6$ years. There was 1 cyst in 89 patients (76\%); there were multiple cysts in 29 patients $(26 \%)$. The mean cyst diameter was $6.3 \pm 1.9 \mathrm{~cm}$. Of the 191 dominant cysts, 140 (92\%) underwent partial cystectomydrainage, $13(8 \%)$ underwent partial cystectomy-drainage and $\mathrm{T}$ tube, $8(6 \%)$ underwent partial cystectomy-drainage and 
omentoplasty and 30 (25\%) underwent partial cystectomydrainage and cholecystectomy.

In the cyst size analysis between CBF present (group 2, $\mathrm{n}=19$ ) and absent (group 1, n=99); in the present group the cyst size was bigger than the absent group $(7.5 \pm 2.4 \mathrm{~cm}$ vs $6.1 \pm 1.8 \mathrm{~cm}$ $\mathrm{p}=0.003)$. On the receiver operating characteristic curve, the $100 \%$ sensitive, $100 \%$ specific, and optimal cutoffs of cyst diameter were $7.5 \mathrm{~cm}, 4.0 \mathrm{~cm}$ and $14.6 \mathrm{~cm}$, respectively. The area under the ROC curve was 0.67 (Figure 2). According to Gharbi classification; in the CBF present group, there were type 2 in eight patients, type 3 in six patients and type 4 in four patients. There was no significant difference between two groups $(\mathrm{p}=0.13)$ (Table 1).

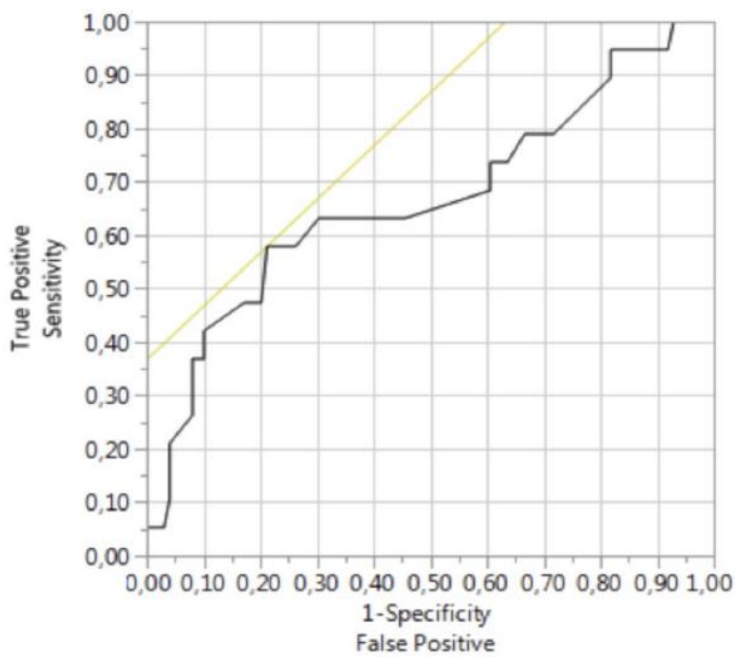

Figure 2. ROC curve analysis for cyst diameter. Area under curve: 0.67

Laboratory results are summarized on the table 2 and in the CBF present group cyst size, WBC, ALP, and GGT levels were higher than group 1 on univariate analysis $(p=0.03$, $\mathrm{p}=0.008, \mathrm{p}=0.04$ and $\mathrm{p}=0.001$, respectively) (Table 2). All of the variables (size, WBC, ALP and GGT levels) that could be assessed before operation were included in multivariate model. In the multivariate model, only cyst diameter remained as an independent predictor (odds ratio $0.03,95 \%$ confidence interval 0.002 to $0.06 ; \mathrm{p}=0.03$; Table 3 ).

Table 1. Demographic and cyst characteristics of patients with or without a cystobiliary fistula.

\begin{tabular}{|c|c|c|c|c|}
\hline Parameters & Overall & $\begin{array}{l}\text { Cystobiliary } \\
\text { fistula present } \\
(\mathrm{n}=19)\end{array}$ & $\begin{array}{l}\text { Cystobiliary } \\
\text { fistula absent } \\
(\mathrm{n}=99)\end{array}$ & $\mathrm{p}$ value \\
\hline Age (mean \pm sd) & $41.9 \pm 16.6$ & $39.7 \pm 15,5$ & $42.4 \pm 16.9$ & 0.51 \\
\hline Gender, n (\%) & & & & 0.11 \\
\hline Female & $74(63)$ & 15 & 59 & \\
\hline Male & $44(37)$ & 4 & 40 & \\
\hline Cyst number, n (\%) & & & & 0.86 \\
\hline Single & $85(72)$ & 14 & 71 & \\
\hline Multiple & $33(28)$ & 5 & 28 & \\
\hline Cyst location, n (\%) & & & & 0.95 \\
\hline Right & $84(71)$ & 14 & 70 & \\
\hline Left & $8(7)$ & 1 & 7 & \\
\hline Right and left & $26(22)$ & 4 & 22 & \\
\hline Cyst size (cm) & $6.3 \pm 1.9$ & $7.5 \pm 2.4$ & $6.1 \pm 1.8$ & 0.03 \\
\hline Cyst type & & & & 0.13 \\
\hline 1 & 5 & 1 & 4 & \\
\hline 2 & 26 & 8 & 18 & \\
\hline 3 & 65 & 6 & 59 & \\
\hline 4 & 20 & 4 & 16 & \\
\hline 5 & 2 & 0 & 2 & \\
\hline
\end{tabular}

SD: standard deviation
Table 2. The relation of the preoperative laboratory results and cystobiliary fistula present or absent.

\begin{tabular}{|c|c|c|c|}
\hline Parameters & $\begin{array}{c}\text { Cystobiliary } \\
\text { fistula present } \\
(\mathrm{n}=19)\end{array}$ & $\begin{array}{c}\text { Cystobiliary } \\
\text { fistula absent } \\
(\mathrm{n}=99)\end{array}$ & $\mathrm{p}$ value \\
\hline $\begin{array}{l}\text { White blood cell count (per mm3) } \\
(\mathrm{mean} \pm \mathrm{SD})\end{array}$ & $9.93 \pm 2.9$ & $7.83 \pm 2.8$ & 0.008 \\
\hline $\begin{array}{l}\text { Hemoglobin }(\mathrm{g} / \mathrm{dl}) \\
\text { Mean liver function test levels } \\
(\operatorname{mean} \pm \mathrm{SD})\end{array}$ & $11.7 \pm 1.7$ & $12.3 \pm 1.8$ & 0.22 \\
\hline Total bilirubin (mg/dL) & $0.88 \pm 0.5$ & $0.75 \pm 0.6$ & 0.34 \\
\hline Direct bilirubin (mg/dL) & $0.52 \pm 0.4$ & $0.41 \pm 0.5$ & 0.29 \\
\hline Aspartate aminotransferase (U/L) & $43.4 \pm 30.4$ & $40.1 \pm 75.4$ & 0.75 \\
\hline Alanine aminotransferase (U/L) & $46.2 \pm 35.9$ & $42.8 \pm 78.6$ & 0.77 \\
\hline Alkaline phosphatase (U/L) & $124.7 \pm 46.0$ & $82.1 \pm 36.0$ & 0.001 \\
\hline g-Glutamyl transpeptidase (U/L) & $104.9 \pm 70.3$ & $47.1 \pm 48.2$ & 0.001 \\
\hline
\end{tabular}

Intraoperative, 19 patients with biliary leakage in the cyst cavity were performed primarily sutured; three patients with not localized biliary leakage were performed T-tube drainage.

Postoperative, the biliary fistula occurred in 19 patients $(16.1 \%)$. Spontaneous closure occurred in two of them, and performed ERCP and sphincterotomy were performed in the remaining 17 patients. The mean time to fistula closure was 15.3 days (range 11-21). We didn't experienced anaphylactic reaction and mortality in our patients.

Table 3: Multivariate analysis model for predictors of the biliary fistula.

\begin{tabular}{lccc} 
Variables & OR & CI & p value \\
\hline Cyst size $(\mathrm{cm})$ & 0.03 & $0.002-0.06$ & 0.03 \\
White blood cell count $\left(\right.$ per $\left.\mathrm{mm}^{3}\right)$ & 0.07 & $0.14-0.27$ & 0.51 \\
Alkaline phosphatase (U/L) & 0.018 & $0.001-0.037$ & 0.07 \\
g-Glutamyl transpeptidase (U/L) & 0.004 & $0.009-0.018$ & 0.50
\end{tabular}

OR: Odd ratio, CI: Confidence interval

\section{Discussion}

Hepatic hydatidosis is rare public health problem in the world but is still a common cause of morbidity and mortality in East countries, including Turkey. The aims of surgery are evacuate the cyst content and wall, restrict cavity of cyst; in some cases cyst excision and/or minor/major hepatectomy can be required, according the cyst localization [13]. Biliary fistula is the main reason of morbidity associated with LHC [14]. Some theories have been proposed about the pathophysiology of CBC.

The cyst may compress and destruct the biliary tract, the other theory is small biliary branches in the cyst wall generate high intracystic pressure, resulting in atrophy followed by the rupture of the biliary tract [8,9]. The incidence of biliary communication in patients with hepatic hydatidosis varies in different studies, from $1 \%$ to $17 \%$ [5]. Preoperative or perioperative revealing of $\mathrm{CBF}$ are critical factors in the treatment of LHC. The current series represent a sample of 118 patients who had surgery for LHC at a research and educational hospital. We identified the factors associated with the incidence of CBF in this study. We found no differences in age, gender, number, location, types of cyst, $\mathrm{Hb}, \mathrm{AST}, \mathrm{ALT}$, total/direct bilirubin and CRP count between patients with or without $\mathrm{CBF}$ and the biliary fistula rate is $16.1 \%$. These results are reliable with those of other studies of LHC $[15,16]$.

LHC can be symptomatic according to size and location of cyst [17]. Although the growth rate of cyst shows several variations, about $20 \%$ of cyst grows $1 \mathrm{~cm}$ per year [18] The liver is most common organ (60-70\%) involved with hydatid disease; approximately $20 \%$ of cyst can affect the lung, the brain, muscles, the kidney, bones, the heart and the pancreas [13, 
18]. LHC involves the right lobe in liver $60-85 \%$ and it is usually asymptomatic up to $10 \mathrm{~cm}$ in size [18]. In this study $71 \%$ of cysts were in the right lobe of the liver, $22 \%$ of cysts were in the right and the left in live; but no significant difference was found between the location of the cyst and development of CBF. Alan and colleagues [8] have shown that there is a relation between the cysts in the right lobe and development of CBF; no significant difference was found in the central cysts.

The most common postoperative complication is biliary fistula, if there is communication between the cyst and the biliary tree. Endoscopic or surgical intervention may be necessary in persistent cases with fistula after surgery [19]. Intraoperative diagnosis of cyst-biliary communication can be difficult but preoperative predictive factors assessment of a biliary fistula might help in patients with LHC.

The size of the cyst was found in our series as a significant predictor of biliary fistula; other authors found that a cyst size of $>10.5 \mathrm{~cm}$ is a significant predictor of cyst-biliary fistula had increased morbidity rates after surgery [13, 20]. Demircan et al. [15] reported that a cyst diameter of $>8.5 \mathrm{~cm}$, Atli et al. [21] found that cyst diameter of $>14.5 \mathrm{~cm}$ was an independent predictor factor. We found that the diameter of the cyst was an independent predictor of CBF. The mean cyst diameter was $7.5 \pm 2.4 \mathrm{~cm}$ in patients with biliary fistula versus $6.1 \pm 1.8 \mathrm{~cm}$ in patients without fistula. On the receiver operating characteristic curve, the $100 \%$ sensitive, $100 \%$ specific, and optimal cutoffs of cyst diameter were $7.5 \mathrm{~cm}, 4.0 \mathrm{~cm}$ and 14.6 $\mathrm{cm}$, respectively. The area under the ROC curve was 0.67 . This result suggested that changes in cyst diameter might have a direct relationship with cyst-biliary communication. Our results support those of Kilic et al. [19] who stated that a cyst diameter of $>7.5$ $\mathrm{cm}$ was a risk factor for biliary fistula.

Increased serum ALP, GGT, direct bilirubin levels were reported to be markers for the biliary fistula between hydatid cysts and biliary tree [4, 21, 22]. Additionally Unalp et al. [23] stated that increased WBC levels might related to be for the biliary fistula. Our findings support that increased risk of biliary fistula in patients with increased WBC, ALP and GGT levels.

The main limitation of this study was its retrospective design. It should be stated that the limitation of patient selection might have influenced by the meaning of a selection bias (e.g. underwent liver resection due to cyst location). Therefore the other limitation was the relatively small size of the study group.

In conclusion, preoperative cyst diameter is a valuable parameter for predicting biliary fistula. However, larger prospective studies are needed in this purpose. Our study suggests that cyst size greater than $7.5 \mathrm{~cm}$ is a risk factor for biliary fistula. ERCP might be considered before surgical treatment in selective patients.

\section{References}

1. Jenkins DJ, Romig T, Thompson RC. Emergence/re-emergence of Echinococcus spp.—a global update. Int J Parasitol. 2005;35:1205-19.

2. Romig T, Dinkel A, Mackenstedt U. The present situation of echinococcosis in Europe. Parasitol Int. 2006;55:187.

3. Alper A, Arioglu O, Emre A, Uras A, Okten A Choledochoduodenostomy for intrabiliary rupture of hydatid cyst of liver. Br J Surg. 1987;74:243-5.

4. Atahan K, Kupeli H, Deniz M, Gur S, Cokmez A, Tarcan E. Can occult cystobiliary fistulas in hepatic hydatid disease be predicted before surgery? Int J Med Sci. 2011;8:315-20.

5. Vicente E, Meneu JC, Hervas PL, Nuno J, Quijano Y, Devesa M, et al Management of biliary duct confluence injuries produced by hepatic hydatidosis. World J Surg. 2001;25:1264-9.

6. Karabay Ö, Bostanc1 Ö. Biliary fistula after liver hydatid cyst surgery: Is it a predictable complication? Arch Clin Exp Med. 2018;3:186-9.
7. Saylam B, Coşkun F, Demiriz B, Vural V, Çomçalı B, Tez M. A new and simple score for predicting cystobiliary fistula in patients with hepatic hydatid cysts. Surgery, 2013;153:699-704.

8. Alan B, Kapan M, Teke M, Hattapoğlu S, Arıkanoglu Z. Value of cyst localization to predict cystobiliary communication in patients undergoing conservative surgery with hydatid cyst. Ther Clin Risk Manag. 2016;12:995-1001.

9. Manouras A, Genetzakis M, Antonakis PT, Lagoudianakis E, Pattas M, Papadima A, et al. Endoscopic management of a relapsing hepatic hydatid cyst with intrabiliary rupture: a case report and review of the literature. Can J Gastroenterol. 2007;21:249-53.

10. Erden A, Ormeci N, Fitoz S, Erden I, Tanju S, Genç Y. Intrabiliary rupture of hepatic hydatid cysts: diagnostic accuracy of MR cholangiopancreatography. AJR Am J Roentgenol. 2007;189:W84-9.

11. Chautems R, Buehler LH, Gold B, Chilcott MJ, Morel P, Mentha G. Long term results after complete or incomplete surgical resection of liver hydatid disease. Swiss Med Wkly. 2003;133:258-62.

12. Gharbi HA, Hassine W, Brauner MW, Dupuch K. Ultrasound examination of the hydatic liver. Radiology. 1981;139:459-63.

13. Daradkeh S, Husam EM, Farah G, Sroujieh AS, Abu-Khalaf M Predictors of morbidity and mortality in the surgical management of hydatid cyst of the liver. Langenbeck's Arch Surg. 2007;392:35-9.

14. Valle-Sanz Yd Y, Lorente-Ramos RM. Sonographic and computed tomographic demonstration of hydatid cysts communicating with the biliary tree. J Clin Ultrasound. 2004;32:144-8.

15. Demircan O, Baymus M, Seydaoglu G, Akinoglu A, Sakman G. Occult cystobiliary communication presenting as postop- erative biliary leakage after hydatid liver surgery: are there significant preoperative clinical predictors? Can J Surg. 2006;49:177-84.

16. Yildirgan MI, Başoğlu M, Atamanalp SS, Aydinli B, Balik AA, Celebi F, Ören D. Intrabiliary rupture in liver hydatid cysts: results of 20 years' experience. Acta Chir Belg. 2003;103:621-5.

17. Frider B, Larrieu E, Odriozola M. Long-term outcome of asymptomatic liver hydatidosis. J Hepatol. 1999;30:228-31.

18. Moro PL, Lopera L, Bonifacio N, Gonzales A, Gilman RH, Moro MH Risk factors for canine echinococcosis in an endemic area of Peru. Vet Parasitol. 2005:130:99-104.

19. Kilic M, Yoldas O, Koc M, Keskek M, Karakose N, Ertan T, Tez M. Can biliary-cyst communication be predicted before surgery for hepatic hydatid disease: does size matter? The Am J Surg. 2008;196:732-5.

20. Agarwal S, Sikora SS, Kumar A, Saxena R, Kapoor VK. Bile leaks following surgery for hepatic hydatid disease. Indian $\mathrm{J}$ Gastroenterol. 2005;24:55-8.

21. Atli M, Kama NA, Yuksek YN, Doganay M, Gozalan U, Kologlu M, et al. Intrabiliary rupture of a hepatic hydatid cyst: associated clinical factors and proper management. Arch Surg. 2001;136:1249-55.

22. Kayaalp C, Bzeizi K, Demirbag AE, Akoglu M. Biliary com- plications after hydatid liver surgery: incidence and risk fac- tors. J Gastrointest Surg. 2002;6:706-12.

23. Unalp HR, Baydar B, Kamer E, Yilmaz Y, Issever H, Tarcan E Asymptomatic occult cysto-biliary communication with- out bile into cavity of the liver hydatid cyst: a pitfall in conservative surgery. Int $\mathbf{J}$ Surg. 2009;7:387-91. 